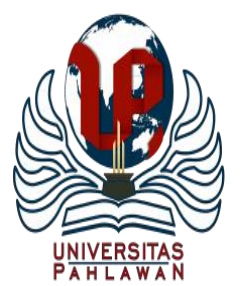

Jurnal Abdidas Volume 1 Nomor 5 Tahun 2020 Halaman 306 - 312

JURNAL ABDIDAS

Community Development Service on Educational and Health Sciences

http://abdidas.org/index.php/abdidas

\title{
Edukasi Pencegahan Penularan Penyakit Akibat Sampah dengan Penggunaan Alat Pelindung Diri (APD) pada Pemulung di TPA Asam Jawa Kabupaten Labuhan Batu Selatan, Sumatera Utara
}

\author{
Restu Auliani $^{1}$, Nelson Tanjung ${ }^{2}$, Debora Sari Simanjuntak ${ }^{3}$ \\ Jurusan Kesehatan Lingkungan, Poltekkes Kemenkes RI Medan \\ E-mail : restuauliani02@yahoo.com ${ }^{1} \underline{\text { tanjung1763@gmail.com }}{ }^{2} \underline{\text { deborasarickp@gmail.com }}{ }^{3}$
}

\begin{abstract}
Abstrak
Penularan penyakit akibat sampah dapat diminimalisir dengan penggunaan Alat Pelindung Diri (APD) oleh pemulung yang bekerja pada TPA Asam Jawa Kabupaten Labuhan Batu Selatan, Sumatera Utara. Masih ditemukan pemulung yang tidak mengunakan APD dalam bekerja selama berkontak langsung dengan sampah. Metode yang digunakan yaitu metode pendidikan masyarakat. Kegiatan ini meliputi survei lapangan, wawancara, edukasi dan sosialisasi, pelatihan dan demonstrasi, serta penyerahan seperangkat Alat Pelindung Diri. Rangkaian kegiatan ini dapat meningkatkatkan kesadaran dan kepedulian pemulung dalam menggunakan APD, untuk meminimalisir risiko penularan penyakit akibat sampah yang ada di lokasi kerja. Kegiatan ini perlu dilakukan secara berkala dan bekerja sama dengan dinas pemerintahan terkait penggunaan APD oleh pemulung upaya meningkatkan derajat kesehatan masyarakat.
\end{abstract}

Kata kunci: alat pelindung diri (APD), pemulung, edukasi

\begin{abstract}
Transmission of diseases caused by garbage can be minimized by using Personal Protective Equipment (PPE) by scavengers who work at TPA Asam Jawa, Labuhan Batu Selatan Regency, North Sumatra. There are still scavengers who do not use PPE in their work as long as they have direct contact with the garbage. The method used is the community education method. These activities include field surveys, interviews, education and outreach, training and demonstrations, as well as submitting a set of Personal Protective Equipment. This series of activities can increase the awareness and concern of scavengers in using PPE, to minimize the risk of disease transmission due to waste in the work site. This activity needs to be carried out regularly and in collaboration with government agencies regarding the use of PPE by scavengers in an effort to improve the degree of public health.
\end{abstract}

Keywords: personal protective equipment (PPE), scavengers, education

Copyright (c) 2020 Restu Auliani, Nelson Tanjung, Debora Sari Simanjuntak

$\triangle$ Corresponding author

Address : Poltekkes Kemenkes RI Medan

ISSN 2721-9224 (Media Cetak)

Email : restuauliani02@yahoo.com

ISSN 2721-9216 (Media Online)

Phone : 085263789425

DOI : https://doi.org/10.31004/abdidas.v1i5.63 

(APD) pada Pemulung di TPA Asam Jawa Kabupaten Labuhan Batu Selatan, Sumatera Utara - Restu Auliani, Nelson Tanjung, Debora Sari Simanjuntak

DOI : https://doi.org/10.31004/abdidas.v1i5.63

\section{PENDAHULUAN}

Masalah keselamatan dan kesehatan kerja secara umum di Indonesia masih sering terabaikan. Hal ini ditunjukkan dengan masih tingginya angka kecelakaan kerja. Salah satu penyebab terjadinya kecelakaan karena tindakan tidak aman dari pekerja, yaitu kurang patuh dalam penggunaan Alat Pelindung Diri (APD) pada saat bekerja (Runtuwarow dkk., 2020:21).

Pemulung sampah beresiko terkena penyakit akibat berkontak langsung dengan sampah, oleh karena itulah diperlukan Alat Pelindung Diri (APD) sebagai perangkat alat yang dipakai oleh tenaga kerja untuk melindungi dirinya terhadap kemungkinan adanya potensi bahaya serta kecelakaan kerja. Sampai saat ini belum terdapat data yang pasti adanya kecelakaan kerja atau penyakit akibat kerja di Tempat Pemrosesan Akhir (TPA), namun risiko adanya gangguan kesehatan atau penyebaran penyakit karena paparan berbagai jenis sampah sangat mungkin terjadi (Sartika dkk., 2020:299).

Berdasarkan risiko pekerjaan, yang memiliki pengaruh besar terhadap keluhan saluran pernapasan pemulung, diketahui bahwa semakin lama pemulung bekerja dan terpapar gas Hidrogen Sulfida $\left(\mathrm{H}_{2} \mathrm{~S}\right)$, maka akan semakin besar risiko mengalami keluhan saluran pernapasan. Semakin lama seseorang bekerja, maka semakin banyak terapapar zat berbahaya ke dalam tubuh oleh lingkungan kerja yang tidak sehat. (Simbolon dkk., 2019:46) hasil penelitian menunjukkan bahwa pengukuran kadar SO2 di dalam sebesar 32,917 $\mu \mathrm{gr} / \mathrm{Nm} 3$. Walaupun kadar SO2 ini masih memenuhi nilai baku mutu, akan tetapi ditemukan persentase keluhan sesak napas pada pemulung di lokasi dalam TPA yaitu sebesar 38,71\% (Fitriana dan Siwiendrayanti 2019:361).

Penelitian lainnya juga menyatakan bahwa terdapat 45 pemulung dari 75 responden pemulung mengalami penyakit kulit (Srisantyorini dan Cahyaningsih 2019:144). Hal ini menunjukkan bahwa ada hubungan antara penggunaan alat pelindung diri dengan keluhan penyakit kulit pada pekerja/pemulung (Andriani dkk., 2020:72). Kemungkinan adanya keluhan penyakit kulit ini adalah kelalaian penggunaan APD oleh pemulung sehingga bisa meningkatkan resiko penyakit kulit.

Rendahnya tingkat pemahaman para pemulung tentang risiko penyebaran penyakit melalui sampah seperti: infeksi saluran pernapasan, gangguan saluran pencernaan (disentri, kolera, typhus, dan lain-lain), parasit kecacingan (cacing kremi, cacing gelang, cacing tambang, dan lain-lain), penyakit kulit, penyakit bawaan tikus (leptospirosis), penyakit bawaan nyamuk (demam berdarah, malaria dan filaria), tetanus, HIV/AIDS, dan Hepatitis C (Gutberlet and Uddin, 2017:309).

Penggunaan APD oleh pemulung berhubungan dengan pengetahuan yang dimiliki pemulung terhadap pentingnya penggunaan APD (Noviyanti dkk., 2020:77). Kelalaian penggunaan APD oleh pemulung dapat menimbulkan akibat buruk karena kegiatan pemulung yang terpapar langsung dengan sampah yang merupakan sumber penyakit harus melindungi diri menggunakan APD. Hal ini harus didukung dengan peningkatan 

Auliani, Nelson Tanjung, Debora Sari Simanjuntak

DOI : https://doi.org/10.31004/abdidas.v1i5.63

pengetahuan pemulung terhadap pentingnya penggunaan APD. Upaya yang perlu dilakukan untuk meningkatkan sikap pekerja antara lain melalui kegiatan pelatihan secara berkala disesuaikan dengan kebutuhan.

Berdasarkan hasil observasi dilapangan, terdapat pemulung yang tidak menggunakan APD bekerja di TPA Asam Jawa di Desa Asam Jawa, Kecamatan Torgamba, Kabupaten Labuhan Batu Selatan, Sumatera Utara, selama bekerja. Jumlah pemulung tetap yang bekerja di TPA Asam Jawa adalah sebanyak 30 orang. Hasil observasi awal menunjukkan terdapat pemulung yang tidak menggunakan masker, sarung tangan serta sepatu booth. Hal ini tentu saja perlu dilakukan kegiatan edukasi terhadap mengingat tingganya resiko penularan penyakit akibat tidak menggunakan APD.

Berdasarkan uraian tersebut, berikut permasalahan yang ditemukan pada pemulung di TPA Asam Jawa. Pertama, terdapat pemulung yang tidak mengunakan APD dalam bekerja selama berkontak langsung dengan sampah. Hal ini tentu saja meningkatkan resiko penularan penyakit yang diakibatkan oleh sampah. Kedua, para pemulung memiliki pengetahuan yang rendah dan wawasan yang cukup mengenai pentingnya penggunaan APD sehingga banyak dari mereka yang tidak menggunakan APD saat bekerja. Pemulung perlu edukasi tentang APD dan pentingnya penggunaan APD. Ketiga, salah satu dalam rangka mengurangi penyebaran penyakit melalui sampah adalah dengan edukasi dan pendampingan tentang penggunaan APD. Melalui kegiatan tersebut dapat mengurangi dan mencegah terjadinya kecelakaan kerja yang berdampak pada pengurangan resiko penyebaran penyakit.

Tujuan kegiatan pengabdian pada masyarakat ini adalah untuk memberikan pendidikan dan pelatihan pengurangan resiko penyebaran penyakit yang dapat ditularkan melalui sampah yang kemungkinan besar ada di TPS. Kegiatan ini dilakukan terhadap sejumlah pemulung yang bekerja mengumpulkan sampah TPA Asam Jawa di Desa Asam Jawa, Kecamatan Torgamba, Kabupaten Labuhan Batu Selatan, Sumatera Utara.

\section{METODE}

Metode pengabdian masyarakat yang digunakan dalam menyelesaikan masalah yaitu metode pendidikan masyarakat. Kegiatan ini dilakukan dengan memberikan penyuluhan berupa adukasi dan sosialisasi penggunaan APD kepada 30 orang pemulung yang ada di TPA Asam Jawa Kecamatan Torgamba, Kabupaten Labuhan Batu Selatan, Sumatera Utara. Tujuan pengabdian masyarakat dengan metode ini yaitu meningkatkan pemahaman dan menanamkan kesadaran diri kepada pemulung terhadap pentingnya penggunaan APD saat bekerja.

Kegiatan edukasi dan sosialisasi dilakukan untuk memberikan pemahaman kepada para pemulung tentang penyakit-penyakit yang bisa ditularkan melalui sampah, jenis-jenis sampah, dan resiko penyebaran penyakit yang bisa menjangkit melalui sampah yang ada di TPA. Dengan demikian, para pemulung mempunyai wawasan 
dan pengetahuan yang cukup untuk mengurangi resiko penyakit yang bisa ditularkan melalui sampah. Kegiatan edukasi dan sosialisasi juga dilakukan untuk memberikan pemahaman kepada para pemulung tentang APD, jenis-jenis APD, fungsi APD dan lain-lain.

\section{HASIL DAN PEMBAHASAN}

Kegiatan Pengabdian Masyarakat (PKM) dilakukan terhadap para pemulung yang beraktivitas di TPA Asam Jawa Kecamatan Torgamba, Kabupaten Labuhan Batu Selatan, Sumatera Utara. Pelaksanaan kegiatan PKM ini meliputi beberapa tahapan, yaitu persiapan, pelaksanaan pendampingan dan evaluasi program.

Tahap persiapan meliputi persiapan alat dan bahan, survei lapangan dan wawancara. Survei lapangan dilakukan dengan mendata para pemulung yang berakivitas di TPA Asam Jawa. Wawancara dilakukan terhadap para pemulung untuk menggali informasi pengetahuan awal para pemulung. Kegiatan ini dilakukan untuk menggali identitas, karakteristik pemulung, riwayat penyakit, pengetahuan dan wawasan pemulung terhadap resiko penyakit menular, pengetahuan dan penggunaan APD. Wawancara dilakukan dengan panduan instrumen cheklist. Dari proses wawancara akan diperoleh informasi mengenai bagaimana para pemulung terpapar resiko penyakit menular dan penggunaan APD.

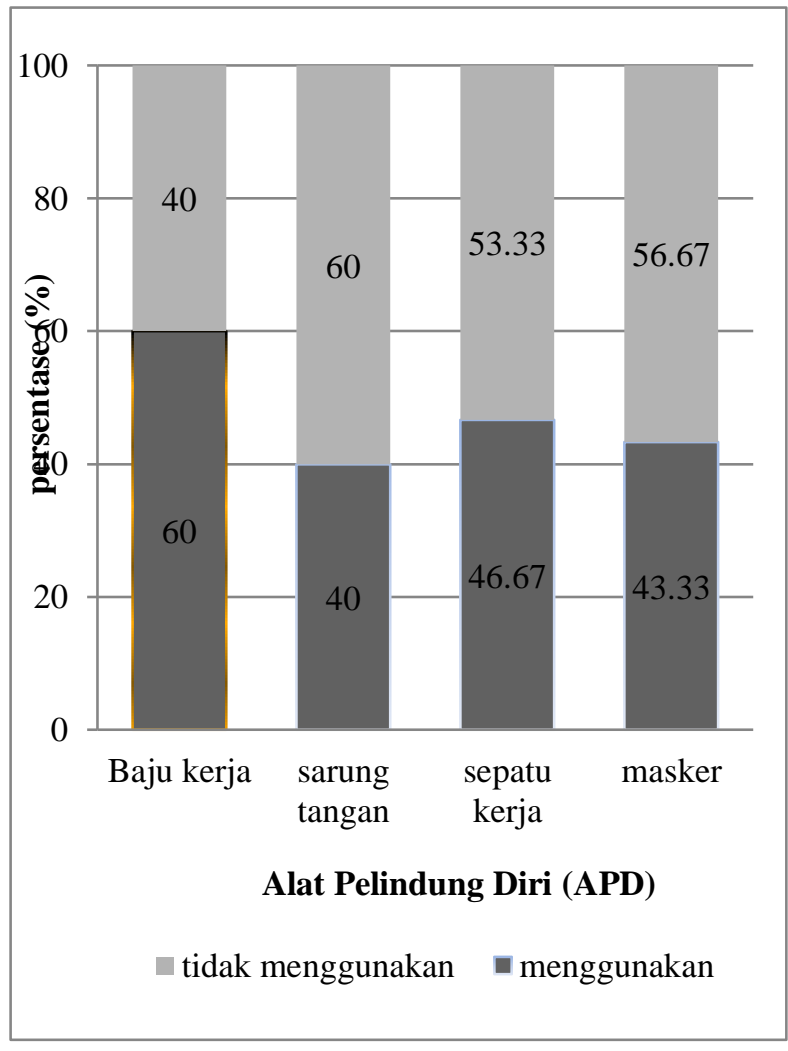

Gambar 1. Persentase penggunaan APD pada pemulung

Berdasarkan hasil wawancara berdasarkan formulir cheklist yang telah disiapkan, diperoleh data masih banyak pemulung yang belum menggunakan APD (Gambar 1). Penggunaan APD pada Gambar 1 melputi jenis baju kerja, sarung tangan, sepatu kerja dan masker. Sebanya $60 \%$ pemulung yang sudah menggunakan baju kerja. Kriteria baju kerja yang dapat melindungi diri, mengganti pakaian kerja setiap hari dengan yang telah dicuci, memiliki lengan panjang yang dapat melindungi diri dari panas matahari dan serangga. Sebanyak $40 \%$ pemulung yang menggunakan sarung tangan selama bekerja. Sarung tangan kebanyakan yang digunakan berupa kantong kresek yang diikat pada bagian pergelangan tangan sebagai pengganti sarung tangan yang tidak 

(APD) pada Pemulung di TPA Asam Jawa Kabupaten Labuhan Batu Selatan, Sumatera Utara - Restu Auliani, Nelson Tanjung, Debora Sari Simanjuntak

DOI : https://doi.org/10.31004/abdidas.v1i5.63

mereka miliki. Pemulung yang menggunakan sepatu yang bisa melindungi kaki dari benda tajam sebanyak 46,67\%. Tapi sepatu yang digunakan tidak semuanya sepatu booth. Sisanya para pemulung hanya menggunakan sepatu seadanya, bahkan ada yang telah terbuka dan juga menggunakan sendal jepit. Sebanyak 43\% pemulung yang menggunakan masker selama bekerja di TPA. Masker yang digunakan berupa masker dari kain atau baju mereka sendiri, tidak sesuai standar kesehatan dan keselamatan kerja (K3).

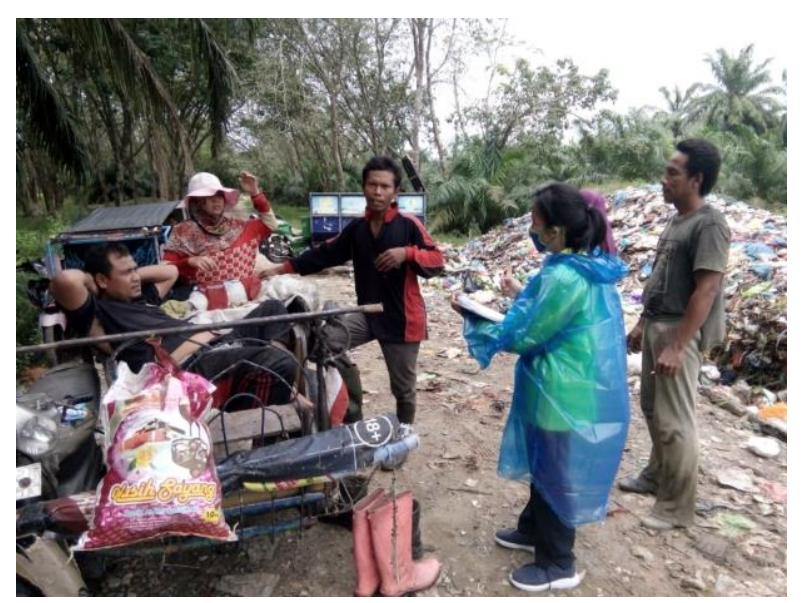

Gambar 2. Kegiatan pendampingan edukasi dan sosialisasi penggunaan APD pada Pemulung do TPA Asam Jawa

Tahap pelaksanaan pendampingan meliputi edukasi dan sosialisasi, demonstrasi dan pemberian bantuan alat pelindung diri. Kegiatan dilakukan dengan cara memberikan informasi kepada para pemulung melalui ceramah dan tanya jawab/diskusi (Gambar 2). Informasi yang disampaikan berupa jenis jenis sampah, penyakit yang bisa ditularkan oleh sampah, dan jenis jenis alat pelindung diri serta fungsinya. Selain itu juga disampaikan mengenai pentingnya penggunaan APD saat bekerja, dan peran APD sebagai pengurangan resiko penyebaran penyakit yang bisa menjangkit melalui sampah yang sering ada di TPA.

Berbagai jenis penyakit yang bisa ditularkan melalui sampah diantaranya adalah penyakit kulit (dermatitis) disebabkan oleh bakteri, virus, parasit ataupun jamur yang tersebar di sampah yang tertimbun di lokasi TPA (Mahyuni, 2012:106). Hal ini juga yang dirasakan oleh kebanyakan pemulung yang ada di TPA Asam Jawa. Penyakit lain yang dirasakan oleh pemulung adalah keluhan batuk, nyeri tenggorokan, pilek dan sesak nafas. Hal ini dikarenakan semakin lama seseorang bekerja, maka semakin banyak terpapar zat berbahaya ke dalam tubuh oleh lingkungan kerja yang tidak sehat (Simbolon dkk., 2019:46). Lingkungan kerja di TPA Asam Jawa sangat berpotensi menimbulkan dampak buruk bagi kesehatan karena kondisi yang kering, berdebu, panas, bau (dari tumpukan sampah). Bau yang timbul dari timbunan sampah berpotensi menimbulkan polusi udara dan dapat mempengaruhi sistem pernafasan.

Kegiatan dilanjutkan dengan pemaparan tentang pentingnya menggunakan APD yang sesuai standar selama bekerja dapat menurunkan resiko penularan penyakit. Pekerja yang patuh akan selalu berperilaku aman dalam melaksanakan pekerjaannya, sehingga dapat mengurangi jumlah kecelakaan kerja yang dalam hal ini bisa terhindar dari penyakit akibat sampah. Sebaliknya pekerja yang tidak patuh akan cenderung melakukan 
311 Edukasi Pencegahan Penularan Penyakit Akibat Sampah dengan Penggunaan Alat Pelindung Diri (APD) pada Pemulung di TPA Asam Jawa Kabupaten Labuhan Batu Selatan, Sumatera Utara - Restu Auliani, Nelson Tanjung, Debora Sari Simanjuntak

DOI : https://doi.org/10.31004/abdidas.v1i5.63

kesalahan dalam setiap proses kerja karena tidak mematuhi standar dan peraturan yang ada (Runtuwarrow dkk., 2020:25).

Kegiatan dilanjutkan dengan demonstrasi penggunaan APD dan pemberian beberapa APD seperti masker dan sarung tangan karet. Diharapkan dengan diberikan bantuan berupa APD dapat merangsang dan meningkatkan kesadaran pemulung akan pentingnya penggunaan APD dalam menjaga kesehatan selama bekerja. Hal ini juga sebagai langkah awal terhadap upaya mengurangi pemaparan penyakit akibat sampah. Diperlukan sosialisasi secara berkala dan pemantauan terhadap pemulung untuk dapat melihat konsistensi pemulung dalam menggunakan APD selama bekerja sehingga dapat meminimalisir risiko penularan penyakit oleh sampah. Peneliti menyadari dalam perubahan perilaku dan sikap terhadap penggunaan APD belum tentu bisa berubah dalam sekali penyampaian edukasi dan sosialisasi seperti yang telah dilaksanakan. Evaluasi dilakukan 1 minggu kemudian untuk memastikan pemulung yang telah dilakukan edukasi dan sosialisasi masih menggunakan APD selama bekerja di Lokasi TPA Asam Jawa.

\section{SIMPULAN}

Kegiatan pengabdian masyarakat dilaksakan pada 30 orang pemulung di TPA Asam Jawa Kecamatan Torgamba, Kabupaten Labuhan Batu Selatan, Sumatera Utara. Kegiatan dilakukan dengan cara edukasi, sosialisasi, demonstrasi dan pemberian bantuan alat pelindung diri kepada pemulung. Rangkaian kegiatan ini diharapkan dapat meningkatkatkan kesadaran dan kepedulian pemulung dalam menggunakan APD, untuk meminimalisir resiko penularan penyakit akibat sampah yang ada di lokasi kerja. Kegiatan ini perlu dilakukan secara berkala dan bekerja sama dengan dinas pemerintahan terkait dalam upaya meningkatkan derajat kesehatan masyarakat.

\section{DAFTAR PUSTAKA}

Andriani, Rininta, Nur Hudayah, and Hasmina. 2020. "Rininta Andriani." Jurnal Kesehatan Global 3(2): 69-75.

Fitriana, Dian, and Arum Siwiendrayanti. 2019. "Kualitas Udara Dan Keluhan Sesak Napas Pemulung Di Tempat Pembuangan Akhir." Higeia Journal of Public Health Research and Development 3(3): 357-68.

Gutberlet, Jutta, and Sayed Mohammad Nazim Uddin. 2017. "Household Waste and Health Risks Affecting Waste Pickers and the Environment in Low- and Middle-Income Countries." International Journal of Occupational and Environmental Health 23(4): 299-310.

Mahyuni, Eka Lestari. 2012. "Dermatosis (Kelainan Kulit) Ditinjau Dari Aspek Keselamatan Dan Kesehatan Kerja Pada Pemulung Di Tpa Terjun Medan Marelan." Dermatosis (Kelainan Kulit) Ditinjau Dari Aspek Keselamatan Dan Kesehatan Kerja Pada Pemulung Di Tpa Terjun Medan Marelan 11(2): 101-9.

Noviyanti, Ulla Amaliah Rizqi, and Muhammad Iqbal. 2020. "Pengetahuan Dan Sikap Pekerja Terhadap Penggunaan Alat Pelindung Diri (APD) Pada Pekerja Blasting Painting Di Kota Batam.” Jural Abdidas 1(3): 88-94.

Runtuwarrow, Yunus Novel, Paul Arthur Tennov Kawatu, and Sri Seprianto Maddusa. 2020. "Journal Of." Indonesian Journal of public Health and Community Medicine 1(April): 21-26. 
312 Edukasi Pencegahan Penularan Penyakit Akibat Sampah dengan Penggunaan Alat Pelindung Diri (APD) pada Pemulung di TPA Asam Jawa Kabupaten Labuhan Batu Selatan, Sumatera Utara - Restu Auliani, Nelson Tanjung, Debora Sari Simanjuntak

DOI : https://doi.org/10.31004/abdidas.v1i5.63

Sartika, Fera, Suratno, and Nurhalina. 2020. "Pendampingan Aplikasi Alat Pelindung Diri Pada Pemulung Sampah Di Kelurahan Langkai Kota Palangka Raya.” Jurnal Ilmiah pengabdian kepada Mayarakat 5(3): 299304.

Simbolon, Veronika Amelia, Nurmaini Nurmaini, and Wirsal Hasan. 2019. "Pengaruh Pajanan Gas Hidrogen Sulfida (H2S) Terhadap Keluhan Saluran Pernafasan Pada Pemulung Di Tempat Pembuangan Akhir (TPA) Ganet Kota Tanjungpinang Tahun 2018." Jurnal Kesehatan Lingkungan Indonesia 18(1): 42.

Srisantyorini, Triana, and Nita Fitria Cahyaningsih. 2019. "Analisis Kejadian Penyakit Kulit Pada Pemulung Di Tempat Pengolahan Sampah Terpadu (TPST) Kelurahan Sumur Batu Kecamatan Bantar Gebang Kota Bekasi." Jurnal Kedokteran dan Kesehatan 15(2): 135. 